\title{
O setor saúde na perspectiva da economia política: a subsunção no trabalho médico
}

\author{
José Carlisson dos Nascimento SANTOS(1) \\ Valéria Andrade SILVA ${ }^{(1)}$ \\ Fernanda ESPERIDIÃO ${ }^{(1)}$ \\ César Ricardo Siqueira BOLAÑO ${ }^{(1)}$
}

Recebido: 28 jan 2019

Aceito: 10 fev 2019

Autor de

correspondência:

jcarlissonsantos@gmail.com

Conflito de interesses: Os autores declaram não haver nenhum interesse profissional ou pessoal que possa gerar conflito de interesses em relação a este manuscrito.

\author{
(1)Programa Acadêmico de Pós-Graduação em Economia, Universidade Federal de \\ Sergipe - UFS, Aracaju, SE, Brasil.
}

\section{Resumo}

O grande desafio que o momento atual nos coloca é exatamente buscar a solvência em ambiente de crescimento da insolvência, buscar a igualdade em ambiente de aprofundamento das desigualdades e buscar um olhar solidário e fraternal em ambiente radicalizado e individualista. A busca do resgate do mutualismo no campo da saúde suplementar, e por extensão no campo da saúde como um todo, este trabalho utiliza o conceito de bem comum presente em Hardt e Negri, com o objetivo de prospectar interesses comuns que possibilitem restabelecimento e consolidação do mutualismo na saúde suplementar. $O$ mutualismo é princípio fundamental que constitui a base de toda relação securitária, já que se trata de um movimento associativo de solidariedade social privada, que, portanto, exige a prática de ações solidárias. Essas ações, entretanto, seriam inviáveis a partir da ação individualizada dos beneficiários ou mesmo das operadoras de plano de saúde. Assim, com o fito de assegurar a unicidade do sistema como requisito fundamental ao mutualismo e, por extensão à sobrevivência do setor, a Agência Nacional de Saúde Suplementar - ANS surge como a única entidade capaz de promover este movimento associativo. Ocorre, entretanto, que a crise pela qual estamos passando se espraia para além da conjuntura econômica, atingindo também as instituições públicas e privadas. No setor da saúde suplementar, sintomas dessa crise vão para além da redução do número de beneficiários nos últimos três anos. Buscando a sobrevivência, as operadoras de planos de saúde passaram a investir numa lógica de oferta de contratos de curto prazo para pequenos grupos, promovendo assim a seleção de risco no setor. Se levado ao paroxismo, esse movimento pode chegar num tratamento caso a caso, destruindo completamente o movimento associativo, que é precisamente a base do mutualismo e da existência do setor. Metodologia: é sabido que a busca pelo interesse comum é examinada em um contexto dinâmico e em um espaço estruturado de posições, nem sempre harmoniosas, iguais ou convergentes. Apesar das divergências, é possível identificar e extrair alguns elementos comuns que contribuem para o resgate da ideia de mutualismo. A partir da identificação e sistematização desses elementos comuns, foi possível estabelecer um conjunto de ações que, uma vez desenvolvidas em 
conjunto, podem contribuir para a redução de custos no setor e, consequentemente, para a viabilidade futura do sistema de saúde. O método para identificação desses elementos se baseou numa análise empírica e qualitativa dos principais fatores geradores ou amplificadores de custos no setor. Importante destacar que a redução de custos atende aos interesses comuns seja o dos segurados ou dos seguradores. Resultados: foram elencadas algumas ações regulatórias significativas que, uma vez adotadas pela ANS, poderão contribuir de forma significativa para o resgate do mutualismo e, por extensão, para a redução dos custos da saúde e melhoria do equilíbrio econômico-financeiro do setor. Conclusões: não obstante as buscas por reavivar os debates sobre a determinação social da saúde a partir de uma agenda mais participativa, esses esforços ficaram distantes de ser alcançados. Na esfera mundial, isso pode ser atribuído ao processo de desmantelamento da ordem mundial manifesta a partir das dimensões política e econômica. Mais recentemente, com o aprofundamento dos efeitos da crise internacional de 2008 e com o ressurgimento de coalizões governistas menos comprometidas com a determinação social da saúde, os objetivos da Saúde Coletiva têm se tornado ainda mais distantes. No caso brasileiro, além da crise de financiamento do Sistema Público e num contexto de radical transição demográfica, vem se observando na esfera privada um comportamento defensivo por parte dos agentes econômicos, levando à deterioração do mutualismo. Este trabalho procurou contribuir para ampliar o debate em torno de uma agenda ainda vigente, que coloca a saúde como um direito humano fundamental. Para tanto, propõe o desenvolvimento de uma agenda mínima que contribua para o resgate do mutualismo e da sustentabilidade econômico-financeira da Saúde Suplementar e por extensão da Saúde como um todo.

Descritores: Economia da Saúde; Médico; Saúde Pública; Trabalho. 